\title{
Cultural Heritage as a Resource for English as an Additional Language Learner: An Out-of Class Approach
}

\author{
Marta García-Sampedro \\ Education Sciences Department, Faculty of Teacher Training and Education, University of Oviedo, Spain
}

Copyright $\mathrm{C} 2018$ by authors, all rights reserved. Authors agree that this article remains permanently open access under the terms of the Creative Commons Attribution License 4.0 International License

\begin{abstract}
This article introduces "Learning Outside the Classroom", a project based on the use of cultural heritage elements as resources or contexts to foster primary and secondary students' oral communication skills in English as an additional language. The main objectives of the project have been to improve students' oral communication level in the English language, to get to know the school's surroundings and learn about the cultural heritage in the area, to develop a taste and an appreciation for art and heritage and to improve students' and teachers' motivation. Most of the activities have been carried out in non-formal spaces such as museums, art galleries, parks or historical buildings. The methodology used in the research of this project, which has been led by the Education Sciences Department at the University of Oviedo, allowed the author to assess and validate its design. This qualitative research has been based on Lewin's action-research principles: Planning, action, observation and reflection. The tools put to use have been the ethnographic observation (participant and non-participant) and the discussion groups. The observation results have shown an increase in students' and teachers' motivation levels due to the use of non-formal spaces and heritage elements as resources. Reflection about the development of the project has provided new guidelines to re-start the action-research process again.
\end{abstract}

Keywords Oral Communication in the English Language, Cultural Heritage, Learning in Non-formal Spaces

\section{Introduction}

Rowe \& Humphries [1] consider teaching to be a valuable, real and relevant values system which should be instilled in children for their future adult lives and believe that the educational process happens not only through instruction but through interaction with other living things. Every child should grow up feeling like he or she is an active member of a group in which language is a fundamental factor of interaction. This belief reflects the importance of interaction in the teaching and learning processes, closely connected to Vygotski's ideas [2].

In the specific case of Spain, the lack of development of the communicative competence in foreign languages is an evident fact, as national and international reports conclude. Oral communication in English as an additional language does not reach the expected levels if we refer to the results obtained in Spanish national assessments, which do not indicating better results than the international evaluation reports. The traditional language teaching approaches used focus on grammar and vocabulary and forget the promotion of oral skills, especially speaking. Bearing this in mind, a methodological change should be made in the country. From the national and regional governments a great effort is being done in this sense but many teachers in service are not receiving special training in the teaching of oral skills.

Initiatives such as the project presented here and some others are an example of how to promote oral skills. Learning out-of-class implies learning in non-formal settings what generates higher students' motivation and experiential learning. The use of heritage as a resource or a context implies significant and memorable experiences for the students in which art and heritage become an excuse to produce oracy. Students' spontaneity and their desire to speak can be observed in every visit.

Considering all these factors, the project "Learning outside the classroom" arose from the search for an actional perspective at the Department of Teacher Training and Education at the University of Oviedo, Spain. This project promotes oral communication in the English classroom using cultural heritage as a resource or a context for learning. Visits to art galleries, museums, historical buildings or parks are carried out to foster learning in non-formal spaces. 
The project started at the university, with the teacher training programs and, around the same time, some experiences were put into practice at a private school in the city of Oviedo. The implementation of the project in primary and secondary education and its research and assessment helped modify the original proposal whose final design was reached in 2016.

Calbó, Juanola y Vallés [3] point out that learning through heritage contexts generates perception processes and allows learners to express emotions, make decisions, state views with respect to places and objects, develop cooperative work, promote cross-curricular activities; it familiarizes the students with traditional jobs and, at the same time, with new technologies. If these learning processes are applied to the field of Foreign Languages, unlimited oracy skills practice, opportunities and experiences will be possible. Learners require experiences in order to have something to say or share, they enjoy being able to have something to talk about and they enjoy being given the opportunity to express their opinions. For these reasons, the use of heritage, as a resource or a context, provides authentic situations in which participants can start dialogues, share sensations, express feelings and exchange opinions.

Learning out-of-class is the other important pillar on which this project rests. In this project the students are given the opportunity to get out of the classroom to get to know surrounding heritage spaces and given the chance to practice their oral communication skills in the English language. These non-formal spaces, as Asensio [4] explains, provide better learning results than formal spaces. This idea, however, clashes with the traditional language teaching approaches which are still in use in many parts of the world, that insist on the use of proper classrooms as the best places for education.

\section{Project}

The project "Learning Outside the Classroom is based on the use of heritage resources, found along streets or in museums, art galleries, historical buildings or parks to promote linguistic and artistic activities with the main aim of improving oral communication in English as an additional language (EAL). Visits are organized depending on the content and objectives planned each term and, also depending on the offer made available by each cultural institution.

\subsection{Theoretical Framework}

This project is a practical, real and constructive alternative to the traditional teaching models. It promotes interaction among the students themselves, the students and the teachers and, additionally, the students and the heritage spaces and objects. With this in mind, a reflection on Vygotski's theory on interaction seems appropriate.
As Moll [5] says, Vygotski has developed a theory on interaction in which humans interact indirectly with their environment through mediation instruments including cultural resources and artefacts - considering oral and written language to be one of them. These cultural artefacts or elements - including speaking, play an important role in the creation of intellectual human capacities. When using these elements, human beings not only mediate interactions but also build social environments. It can be said that Vygotski understands language to be a basic tool that provides humans with access to the world. For this reason, it is necessary to strive to expand our contact with other humans, in different contexts, while experiencing new communicative situations as they arise in "Learning Outside the Classroom".

Following Vygotski's theories, culture is defined as the social and material experiences developed and historically accumulated by human beings. That is to say, culture is the social environment and people's lives are center stage. Human beings engage in thinking when they are using cultural artefacts, especially with the help of oral and written language [5] and for this reason, culture is so important to the language learning process.

\subsection{Project Objectives}

The project's objectives are to improve students' oral communication in the English language, to get to know the school surroundings and its cultural heritage, to develop a taste and appreciation for art and heritage, and to improve students' and teachers' motivation.

\subsection{Project Activities and Resources}

Following Goh \& Burns [6] ideas, all the project activities share the same principles: to promote students' oral skills to help them in their academic learning and social life; to focus activities on linguistic forms, speech structure and vocabulary to develop oral skills; to support and strengthen students' interaction and to encourage creative dialogue and discussions among students and teachers.

Activities are always organized in three blocks: Classroom activities (before the visit), Outside school activities (during the visit) and Classroom activities (after the visit).

\section{Method}

The methodology used in the research of this project allowed the author time to assess and validate its design. It was a qualitative research based on Lewin's [7] action-research principles: Planning, action, observation and reflection. The research techniques used were participant observation, non-participant observation (during the observation stage) and discussion groups 
(during the reflection stage). The project was developed in two different schools in the city of Oviedo and around 150 pupils participated. The students were divided in groups of 12/15 and one of the school's English teachers worked with them during the visits.

The project was assessed through observation (participant and non-participant observation) and through two different focus groups.

Participant observation was developed throughout the visits via field notes, research diary, photographs and audio and video recordings made with mobile phones. All of these tools allow to collect a lot of data. To systematize and structure the gathered information four analysis categories were established. These categories were: Contexts, Interaction, English Language and Motivation. The information related to contexts was obtained through photographs taken in the field which helped describe context and environment and understand the educational settings. Through audio and video recordings interaction among students, students and teachers and students and settings could be analyzed besides the type of oral texts students were able to produce and linguistic aspects such as pronunciation, intonation or grammar structures used by them. It was also possible to appreciate the interest for the local environment, art and culture and students behavior during the visit.

Non-participant observation was carried out by an external observer who used the same tools as the participant observers and filled in different templates with her impressions. In this case, the analyzing categories were the same: Contexts, Interaction, English language and Motivation.

Focus groups were the other instrument used to assess the project. As it has been said before, two focus groups were arranged in two different universities.

The first focus group was carried out with university lecturers at the Faculty of Teacher Training and Education at a university in the north of Spain and the goal was to evaluate and validate the project "Learning Outside the Classroom". This focus group was made up of eight lecturers and a moderator and four analyzing categories were established before starting: Oral communication, Learning in non-formal spaces, Motivation and two other resultant categories arose: Evaluation and Methodology.

The second focus group took place at the Institute of Education, in a well-known British university. The categories used to analyze the information were the same as with the first group but with the addition of a new category which arose during the discussion: the psychological perspective of learning.

\subsection{Results of Research}

\subsubsection{Participant and Non-participant Observation Results}

Contexts. The indoor and outdoor contexts used for the implementation of the project were suitable for the project, the most outstanding of all being the Colegio Oficial de
Arquitectos de Asturias and Banco Sabadell exhibition spaces, both situated in Oviedo.

Interaction. The interaction among students, students and teachers, and students and heritage objects was excellent.

English language. In terms of the English language spoken, attention was focused on the diverse linguistic elements from the communicative and linguistic competences, such as pronunciation and intonation. Observation meant researchers could check the language acquisition process in real situations, which helped researchers design activities to improve its treatment in the classroom. In addition, pragmatic-discursive aspects such as the types of oral texts that students are able to produce in each school level, were clarified. Therefore, it revealed that in primary school, students can produce dialogic and descriptive texts. Likewise, in the 5th and 6th grade they can produce narrative, descriptive and dialogic texts. Afterwards, in secondary school, texts promoting debate can be introduced.

Motivation. Motivation is a key factor in the language learning process. In this project, thanks to the participant observation, students' motivation was monitored when they went outside the school, visited the surroundings and undertook activities in non-formal spaces. As a result, it was found that rather than lecturing, students were more motivated when doing hands-on activities outside of the classroom.

\subsubsection{Focus Groups Results}

The experts participating in the first focus group considered the project a very interesting and innovative proposal because of the use of the cultural heritage and because of the use of formal and non-formal spaces for learning. The combination of a CLIL (Content and Language Integrated English) perspective and an actional perspective was also recognized as a novelty. The project promotes experiential learning, and for this reason, different ways of assessing such as peer-assessment or self-assessment were proposed. Motivation is another important category that shows excellent results in the project. Students were highly motivated when participating in the project. In addition, the experts who took part in the second focus group, who know the reality of the Spanish education system, considered the project a brave and risky example because, among other objectives, it aims to change or challenge the minds or ideas of traditional teachers. This second focus group suggested changing the name of the project and framed the project in the theoretical perspective of social constructivism combined with experiential learning. Another suggestion was to allow children to use two languages (in this case, Spanish and English) so every student has the chance to speak if they really want to. These experts also suggested using the term English as an Additional Language which is used nowadays to refer to English as a second language or as a foreign language. They added that the project promotes 
motivation especially for working outside of the school and by "learning by doing" pointing out that one of the main advantages of the proposal was the cross-curricular interaction of different elements such as, language, art and media.

\subsection{Limitations}

The project has presented some limitations related to the organization of the visits. Although the heritage spaces chosen are not far from the school center, there is always an element of risk taking children out of the school. Parents have to sign a document through which, they allow their child to participate in these activities outside the school. In the case of this project, teachers and students visited the places on foot because the distances were short - no longer than 10 or 15 minutes walking. The city has a lot of pedestrian streets which is an advantage for the project.

\section{Discussion}

As previously shown, the project Learning Outside the Classroom follows the action-research principles - it is an example of a constructive proposal with an actional perspective. As with some other projects in the region [6], Learning Outside the Classroom tries to promote English as an additional language in Primary and Secondary Education through the use of non-formal heritage spaces as context or resource. Some previous experiences (Colegio San Fernando de Avilés) used heritage as a resource in a project where secondary students acted as tour guides in the city of Avilés, Asturias, as the main objective of the project was the promotion of communicative skills in English as an additional language. As the action-research methodology implies, new cycles of research are started every year, including the planning of new actions and activities or analyzing categories as a result of the reflection.

\section{Conclusions}

"Learning Outside the Classroom" is a project which started at the Faculty of Teacher Training and Education at the University of Oviedo, and, at the same time, was able to be implemented in two schools in Oviedo, Spain. The purpose of the project is to promote oral communication in the English language combining oral language teaching, non-formal spaces for learning and the use of cultural heritage as a resource and/or as a context. Learning out-of-class provides the necessary experiences to produce oracy and promotes a creative dialogue among students and teachers. As observed by Asensio [4], the ample spaces used for the experiential activities, which usually take place on the floor, have a significant impact on the students learning.

This project's aims "to take the school to the world outside and bring the world inside the school" García-Sampedro y Calaf [9] were fulfilled. Also, the purposes of the project relating to building on students' cultural identity and developing their cultural competence were also achieved, considering these contents or contexts cannot always be achieved by families due to different factors (lack of knowledge, nationality, resources or training). The proposal moves between formal spaces like the classroom and non-formal spaces, such as museums, galleries, historical buildings, etc. Likewise, it promotes a taste and appreciation for art and heritage by learning about and discovering things about the local environment. Lastly, practicing oral communication in the English language through a dialogical approach provides exciting experiences to promote oracy.

The action-research process, based on the four stages: planning, action, observation and reflection allowed the author to re-start the project every year modifying the required aspects. Observation allowed the researchers to know that interaction among students, teachers and spaces was excellent; Observing the language acquisition process in real situations was made possible and helped researchers to re-design activities to improve its treatment in the classroom, too. On the other hand, the results show the importance of students' and teachers' motivation in the additional language acquisition process and how non-formal contexts have a great influence on this.

The focus groups evaluated and validated the design of the project "Learning Outside the Classroom" which was theoretically framed in Vygotsky's constructivism and experiential principles and considered it an educational innovation based on an active perspective and CLIL. This framework was highly valued by the focus groups because it encourages student and teacher motivation by combining different elements such as language, heritage education, $\mathrm{m}$-learning and a cross-curricular approach.

\section{Acknowledgements}

We would like to thank the following institutions their help and support during the research process: Colegio Oficial de Arquitectos de Asturias, Oviedo (Pepe Vázquez de Prada), Sala de Exposiciones del Banco Sabadell (Oviedo), Museo de Bellas Artes de Asturias, Institute of Education-University College London (Anne Chowne and Kenna Worthington), Courtauld Gallery London (Learning Department), The British Museum (Learning Department) and the William Morris Gallery (Learning Department).

\section{REFERENCES}

[1] S. Rowe, S. Humphries. The Coombes approach. Learning through an experimental and outdoor curriculum, Continuum, London, 2012. 
[2] L. S. Vygotski. Thought and language, Harvard University Press, Cambridge, 1986.

[3] M. Calbó, R. Juanola, J. Vallés. (2011). Visiones interdisciplinarias en educación del patrimonio: Artes, cultura y ambiente, Documenta Universitaria, Girona, 2011.

[4] M. Asensio. El aprendizaje natural, la mejor vía de acercarse al patrimonio, Educatio Siglo XXI, 33 (1), 55-82, 2015.

[5] L. C. Moll. Vygotski, la educación y la cultura en acción, in A. Álvarez (Ed.), Hacia un curriculum cultural: La vigencia de Vygotski en la educación, Fundación Infancia y Aprendizaje, Madrid, 75-87,1997.

[6] C. Goh, A. Burns. Teaching Speaking, Cambridge University Press, Cambridge, 2012.

[7] K. Lewin. Action research and minority problems, Journal of Social Issues, 2 (4), 34-46, 1946.

[8] M. García-Sampedro. Propuestas de innovación para el fomento de la comunicación oral en lengua inglesa en la educación asturiana, in E. López-Meneses (Ed.), Innovación educativa. Aportaciones desde la praxis docente e investigadora, Octaedro, Barcelona, 2018.

[9] M. García-Sampedro, R. Calaf. El patrimonio cultural como contexto experiencial en el proceso de enseñanza-aprendizaje de la lengua inglesa. Actas del II Congreso Internacional de Educación Patrimonial, 109-118, 2014, Online available from http://media.wix.com/ugd/79b 507_680ae82d4e754f5ba6718ca15129a33e.pdf 